\title{
Effect of azaperone in newly calved sows over the progenies' health and performance in maternity and nursery phases
}

\section{Efeito do azaperone em porcas recém paridas sobre a saúde e o desempenho da progenie nas fases de maternidade e creche}

\author{
Everson Zotti ${ }^{1 *}$; Caio Abércio da Silva ${ }^{2}$; Amauri Alcindo Alfieri²; Ana Maria Bridi²; \\ Camila Perin Welter ${ }^{3}$; Tiago Comarella Souza ${ }^{3}$; Matheus Cauduro Saraiva ${ }^{3}$; \\ Dirceu Celeste Zotti ${ }^{4}$; Fabiane Helena Nogueira Bachega Moreira ${ }^{5}$
}

\begin{abstract}
The aim of this experiment was to evaluate the effects of azaperone administered to sows at the end of farrowing over the health and zootechnical parameters of progenies in the maternity and nursery phases. The experiment was conducted with 120 females, with $1^{\text {st }}, 3^{\text {rd }}$ and $5^{\text {th }}$ parities, and 1,564 born alive piglets. The females of the group treated with azaperone (TG $n=60)$ and control group (CG, $n=60)$ received a deep intramuscular injection, immediately after the placenta elimination, of $8 \mathrm{~mL}$ azaperone $(320 \mathrm{mg})$ and $8 \mathrm{~mL}$ of sterile saline solution, respectively. During the maternity phase ( $\leq 21$ days old) the percentage of piglets with diarrhea of CG $(2.58 \%)$ was significantly different $(\mathrm{P} \leq 0.01)$ compared to the GT $(0.75 \%)$. At the maternity phase there were no significant differences between the treatments to the mortality rate, total and piglets weight with $<1 \mathrm{~kg}$, transfers, crushed, medicated, arthritis and starvation. In the nursery phase, there weren't also significant differences between the treatments. The administration of azaperone had a positive effect over the diarrhea control of piglets until the weaned.
\end{abstract}

Key words: Diarrhea, piglets, peripartum, mortality rates, sedatives, swine

\section{Resumo}

O objetivo deste trabalho foi avaliar os efeitos do uso do azaperone, administrado em porcas ao final do parto, sobre parâmetros sanitários e zootécnicos da progênie nas fases de maternidade e creche. $\mathrm{O}$ experimento foi realizado com 120 fêmeas, de $1^{\mathrm{a}}, 3^{\mathrm{a}}$ e $5^{\mathrm{a}}$ ordens de parto, e 1.564 leitões nascidos vivos. As fêmeas do grupo tratado com azaperone (GT; $n=60)$ e do grupo controle (GC; $n=60)$, imediatamente após a eliminação da placenta, receberam por via intramuscular profunda, respectivamente, $8 \mathrm{~mL}$ de azaperone ( $320 \mathrm{mg})$ e $8 \mathrm{~mL}$ de solução fisiológica estéril. Na fase de maternidade ( $\leq 21$ dias de idade) o percentual de leitões com diarreia no $\mathrm{GC}(2,58 \%)$ foi estatisticamente maior $(\mathrm{P} \leq 0,01)$ em relação ao GT $(0,75 \%)$. Na maternidade não foram observadas diferenças entre os tratamentos para a taxa de mortalidade (total e de leitões nascidos com peso $<1 \mathrm{~kg}$ ), transferências, esmagados, medicados, inanição e artrite. Na fase de creche também não foram observadas diferenças entre os tratamentos. Conclui-se que a administração de azaperone teve efeito na redução da incidência de diarreia de leitões lactentes.

Palavras-chave: Diarréia, leitões, periparto, sedativo, taxa de mortalidade

${ }^{1}$ Prof., Dr., Pontifícia Universidade Católica do Paraná, PUCPR, Toledo, PR. Brasil: E-mail: everson.zotti@pucpr.br

2 Profs. Drs., Universidade Estadual de Londrina, UEL, Londrina, PR. Brasil. E-mail: casilva@uel.br; alfieri@uel.br; ambridi@ hotmail.com

3 Discentes de Graduação, Pontifícia Universidade Católica do Paraná, PUCPR, Toledo, PR. Brasil. E-mail: camilapwelter@ hotmail.com; tiago_comarella@hotmail.com; matheus_saraiva@hotmail.com

4 Supervisor de Suinocultura, Lar, Medianeira, PR, Brasil. E-mail: dirceuzotti@yahoo.com.br

5 Supervisor de Suinocultura, Frimesa, Medianeira, PR, Brasil. E-mail: fomento@frimesa.com.br

Author for correspondence 


\section{Introduction}

Azaperone is a neuroleptic analgesic belonging to the class of butyrophenones with psychomotor depressant action without narcosis (MUIR; HUBBELL, 2001) indicated specifically for pigs. The drug acts primarily as dopamine antagonist but also has antihistamine and anticholinergic properties (STRESNIL, 2009). Additionally, azaperone blocks D2 dopamine receptors, resulting in analgesia without sedation and increased prolactin secretion (RUEDIGER; SCHULZE, 2012).

At low doses, azaperone is mainly indicated to minimize the fights during the mixing of animals for the formation of lots and to reduce the aggressiveness of females after farrowing. When used in the postpartum, it is not reported changes in food consumption, in circulatory and thermoregulatory systems and adverse effects on lactation (STRESNIL, 2009).

Minimizing the stress of sows and piglets during the period of peripartum has a positive effect in improving the consumption of colostrum (MIQUET; VIANA, 2010). Thus, azaperone has been considered a useful tool to improve the colostrum intake, and consequently the performance of piglets. The volume of colostrum produced by females varies from 1.9 to $5.3 \mathrm{~kg}$ regardless the size of the litter, a fact which determines that in large litters there is a higher percentage of piglets that do not ingest sufficient amounts of colostrum (MIQUET; VIANA, 2010). Within 3 hours of life the pig should eat at least 25 to $30 \mathrm{ml}$ of colostrum (STEIN; MURATA, 2002), but immediately after birth some females may show aggressive behavior, affecting negatively the colostrum intake.

Administration of azaperone in sows at the end of farrowing has a positive effect on the number of piglets, that are nursed in the most critical hours after birth regardless of parity order of the sows, keeping them calm and with a behavior that leads to a greater exposure of the mammary gland, allowing the piglets to be nursed with less interruption (JOURQUIN et al., 2010).
The consequences of these actions are positive in enhancing the immune profile of piglets, with effects on performance and survival rate, especially considering the hyper prolificacy of the modern commercial genetic (RUEDIGER; SCHULZE, 2012).

Regarding mortality of piglets in the lactation period, Miquet and Viana (2010) emphasize that factors related to the management, the environment and the quantitative and qualitative aspects of passive immunity transferred to piglets immediately after birth, have influence on the parameters, noting that the most critical factors for piglet survival in the first days of life, are the ability to suckle colostrum, the volume of available colostrum, colostrum quality and female behavior during the colostral phase.

Thus, considering the importance of the quantitative and qualitative aspects of the colostrum in the piglet's immune profile, azaperone, by its properties, can be a tool to enable a higher and more balanced consumption of colostrum among piglets from large litters.

This experiment was conducted to evaluate the influence of the administration of azaperone as a single dose in sows right after farrowing, on some production and health parameters of their offspring, in the period ranging from birth to leaving nursery.

\section{Materials and Methods}

The experiment was conducted in the farrowing and nursery sectors of a commercial farm (Piglet Production Farm) with 5,300 TOPIGS sows, located in the western region of Paraná state.

The treatments consisted of the administration or not of azaperone to sows. In the test group sows at the end of farrowing and immediately after removal of the placenta, received $8 \mathrm{~mL}(320 \mathrm{mg})$ of azaperone (Stresnil ${ }^{\circledR}$ - Janssen-Cilag, Belgium ) by deep intramuscular injection in the base of the ear. Under the same conditions, the control group of females received $8 \mathrm{~mL}$ of sterile saline solution. 
It was evaluated 1564 piglets (males and females) from 120 sows of reproductive age corresponding to the first, third and fifth parity orders, distributed in a randomized block designed with two treatments and three blocks, represented by the parity orders of the sows ( 20 sows by parity order for treatment), with unequal number of repetition per treatment (considering each piglet a repetition, initially treatments showed 790 and 774 piglets).

All litters included in this study were derived only from sows that had normal deliveries without induction with prostaglandin or oxytocin support. In the test group the average of live born pigs was $13.16 /$ sow and in the control group it was 12.90 . The average birth weight was $1.30 \pm 0.33$ and $1.31 \pm 0.32$ $\mathrm{kg}$ for the test and control groups, respectively. The farrowing pens were suspended, they had plastic floor, temperature control by means of curtains, creeps available to piglets $\left(1 \mathrm{~m}^{2}\right.$ area) with heated floors and light bulbs of 200W.

The sows' farrowing were fully monitored and the management procedures on the first day of the piglets' life included drying with dry powder, the orientation of the first suckling, and cutting and disinfection of the navel. On the second day of life, piglets were submitted to the managements of teeth wear, cutting tail and administration of iron dextran (200 mg intramuscular, single dose). None of the groups was allowed to use colostrum supplementation during the trial period.
Immediately after birth, all piglets were weighed and identified and had free access to water and on the $6^{\text {th }}$ day they had access to pre-starter ration (Table 1).

To ensure that all piglets ingest their own mother's colostrum, transfers of piglets among sows were performed only after 18 hours of life, following a pattern consisting of piglets of the same age, from the same parity order females, treated and housed in the same farrowing room. All data collected in the maternity phase were performed by a continuous period of $24 \mathrm{~h}$.

The animals (1564 live born pigs) were individually weighed at birth, seven, 21 (weaning) and 59 days of age (day before leaving nursery). In the period between birth and weaning ( 21 days old) it was evaluated the incidence of arthritis, presence of diarrhea, number of crushed, piglets with inanition, treated and killed. The classification of piglets with diarrhea in the nursery was performed by visual assessment of feces consistency, according to the methodology described by Sobestiansky and Barcellos (2012). Only piglets with creamy and liquid feces were considered for analysis and only one episode of diarrhea was considered by pig per phase, regardless of the time course of clinical signs. For inanition, only animals that did not show clinical signs compatible with diseases were included in this category (MARTINEAU; MORVAN, 2010a). For the identification of animals with arthritis, it was followed the guidelines proposed by Martineau and Morvan (2010b). 
Table 1. Composition and nutritional value of feed used during the trial period.

\begin{tabular}{|c|c|c|c|}
\hline Ingredients & $\begin{array}{l}\text { Pre starter I (\%) } \\
\text { (6 to } 24 \text { days) }\end{array}$ & $\begin{array}{c}\text { Pre starter II (\%) } \\
\text { (25 to } 35 \text { days) }\end{array}$ & $\begin{array}{c}\text { Initial (\%) } \\
\text { (36 to } 60 \text { days) } \\
\end{array}$ \\
\hline Corn Meal & 40,00 & - & - \\
\hline Corn Grain & - & 35,50 & 52,20 \\
\hline Soybean Meal & - & 17,50 & 23,80 \\
\hline Sugar & - & 5,00 & 4,00 \\
\hline Concentrate feed ${ }^{1}$ & 60,00 & - & - \\
\hline Concentrate feed ${ }^{2}$ & - & 42,00 & - \\
\hline Concentrate feed ${ }^{3}$ & - & - & 20,00 \\
\hline \multicolumn{4}{|c|}{ Calculated Nutritional Values } \\
\hline Dry Matter (\%) & 91,59 & 91,58 & 89,75 \\
\hline EM & 3513,62 & 3477,38 & 3411,36 \\
\hline Crude Protein $(\%)$ & 19,2 & 21,4 & 19,50 \\
\hline Crude Fat $(\%)$ & 5,55 & 4,61 & 4,33 \\
\hline Crude Fiber (\%) & 2,19 & 3,30 & 3,15 \\
\hline Lactose $(\%)$ & 14,00 & 9,30 & 4,20 \\
\hline Calcium (\%) & 0,48 & 0,38 & 0,59 \\
\hline Lysine $(\%)$ & 1,22 & 1,25 & 1,06 \\
\hline Methionine (\%) & 0,55 & 0,45 & 0,37 \\
\hline Threonine (\%) & 0,92 & 0,74 & 0,58 \\
\hline Tryptophan (\%) & 0,27 & 0,21 & 0,18 \\
\hline Met+Cist (\%) & 0,85 & 0,72 & 0,62 \\
\hline Valine $(\%)$ & 0,64 & 0,85 & 0,76 \\
\hline Potassium $(\%)$ & 0,87 & 1,07 & 0,81 \\
\hline Sodium $(\%)$ & 0,42 & 0,32 & 0,26 \\
\hline Total Phosphorus (\%) & 0,66 & 0,53 & 0,69 \\
\hline Available Phosphorus (\%) & 0,34 & 0,34 & 0,47 \\
\hline
\end{tabular}

${ }^{1}$ Levels by kg of feed: Ethereal Extract (Min.) - $60.00 \mathrm{~g}$; Crude fiber (max.) - $22.00 \mathrm{~g}$; Lactose (min.) - 212,226g; Lysine (min.) - $20.00 \mathrm{~g}$; Methionine (min.) - 7,000.00 mg; Threonine (min.) - 14,40g; Tryptophan (min.) - 4,320,00mg; Crude protein (min) - 218,07g; Moisture (max.) - 120,00g; (Iron (min) -67,5mg; Calcium (min / max) - 9,500.00 / 11700.00 mg;... Chlorine (min) 10,50g;. Cobalt (min) - 0.36 mg.; Copper (min.) - 14.4 mg, Phosphorus (min.) - 8550.00 mg, Iodine (min.) - 3,06mg; Manganese (min.) - $144.00 \mathrm{mg}$, Potassium (min.) - 11, 00g; Selenium (min.) - $1.08 \mathrm{mg}$, Sodium (min.) -6.000,00mg; Zinc (min.) - 4,500.00 mg, Folic Acid (min.) - 5,40mg; Pantothenic Acid ( $\mathrm{min}$. .) - 30,37 mg, Biotin ( $\mathrm{min})$ - 0,37mg;.. Hill (min) - 1.080,00mg; Thiamine (min) - 5,06mg;. Niacin (min) - 57,37mg;. Vitamin A (min.) - 33375.00 IU, Vitamin B12 (min.) -77.62 $\mu \mathrm{g}$ - Vitamin B2 (min.) 12,15mg; Vitamin B6 (min.) - 6.75 mg, vitamin C (min. ) - 450.00mg; Vitamin D3 (min) - 8775.00 IU;. Vitamin E (min) - 229.50 IU, Vitamin K3 (min) $-8.77 \mathrm{mg}$,. Colistin $-66.67 \mathrm{mg}$.

${ }^{2}$ Levels per kg of feed: Ethereal extract (min.) $-50.00 \mathrm{~g}$; Crude fiber (max.) - $21.00 \mathrm{~g}$; Lactose (min.) - $210.06 \mathrm{~g}$; Lysine (min.) $17.10 \mathrm{~g}$; Methionine (min.) - 6,500.00 mg; Threonine (min.) - 10,89g; Crude protein (min) - 218,34g; Moisture (max.) - 120,00g; Iron (min.) -141,75mg; Calcium (min / max..) - 12.00 / $15.50 \mathrm{mg}$; Chlorine (min.) - $11.25 \mathrm{~g}$; Cobalt (min.) - $0.46 \mathrm{mg}$; Copper (min.) - 18.72 mg; Phosphorus (min.) - 8,000.00 mg; Iodine (min.) - 3,97mg; Manganese (min.) - 187.20 mg; Potassium (min.) - 11.34 g; Selenium (min.) - 1.38 mg; Sodium (min.) - 7,500.00 mg; Zinc (min.) - 7.400,00mg; Folic Acid (min.) - 6.91 mg; Pantothenic Acid (min.) - 38.88 mg; Biotin (min.) - 0,47mg; Hill (min.) -1 .544,00 Mg; Thiamine (min.) - 6,48mg; Niacin (min.) Mg -73.44; Vitamin A (min.) - 43200.00 IU; Vitamin B12 (min.) -99.36 Mg; Vitamin B2 (min.) - 15,55mg; Vitamin B6 (min.) -8,64mg; Vitamin C (min.) - 648,00mg; Vitamin D3 (min.) - 11232.00 IU; Vitamin E (min) - 210.78 IU; Vitamin K3 (min.) Mg -11.23 ; Colistin $-95.24 \mathrm{mg}$.

${ }^{3}$ Levels per kg of feed: Ethereal extract (min.) - 45,99g; Crude fiber (max.) - $33.00 \mathrm{~g}$; Lactose (min.) - $210.06 \mathrm{~g}$; Lysine (min.) $19.53 \mathrm{~g}$; Methionine (min.) - 7.560,00 mg; Crude protein (min) - 209,43g; Moisture (max.) - $120.00 \mathrm{~g}$; Iron (min.) -141,75mg; Calcium (min / max..) - 12.00 / 15.50 mg; Chlorine (min.) - 11,25g; Cobalt (min.) - 0.46 mg; Copper (min.) - $18.72 \mathrm{mg}$; Phosphorus (min.) - 8,000.00 mg; Iodine (min.) - 3,97mg; Manganese (min.) - $187.20 \mathrm{mg}$; Potassium (min.) - $11.34 \mathrm{~g}$; Selenium (min.) 1.38 mg; Sodium (min.) - 7,500.00 mg; Zinc (min.) - 7.400,00mg; Folic Acid (min.) - $6.91 \mathrm{mg}$; Pantothenic Acid (min.) - 38.88 mg; Biotin (min.) - 0,47mg; Hill (min.) -1 .544,00 Mg; Thiamine (min.) - 6,48mg; Niacin (min.) Mg -73.44; Vitamin A (min.) - 43200.00 IU; Vitamin B12 (min.) -99.36 Mg; Vitamin B2 (min.) - 15,55mg; Vitamin B6 (min.) -8,64mg; Vitamin C (min.) 648,00mg; Vitamin D3 (min.) - 11232.00 IU; Vitamin E (min) - 210.78 IU; Vitamin K3 (min.) Mg -11.23; Halquinol - 300.00 mg. 
After weaning, piglets were housed in nursery pens, located on the same farm. The pens were suspended, had plastic floor, gas heating, drinkers nipples and automatic feeders. At the nursery, following the farm management routine, the piglets were separated by weight category in small, medium and large and remained in the same pens or groups until being 60 days old. The management between experimental groups was the same throughout the experiment.

The feeding in the nursery phase was at ease, following the minimum recommendations established by the NRC (1998) (Table 1). At the end of the nursery phase piglets were individually weighed.
Performance data were submitted to analysis of the test $\mathrm{F}$ and the data that did not allow parametric analysis, it was performed the Chi-square test.

\section{Results and Discussion}

The average weights of animals at different ages until the exit of the nursery phase were not different between treatments (Table 2). These results differ from those obtained by Jourquin et al. (2010), and Tseng et al. (2010), who, respectively, have found an increase of 5 to $10 \%$ of weight gain (from birth to weaning) of piglets from sows that received azaperone (320 mg intramuscular, single dose); The litter weaning weight from first parity sows using azaperone was 11.3\% (MIQUET; VIANA, 2010) and $11.2 \%$ higher (RUEDIGER; SCHULZE, 2012) comparing to piglets from untreated sows.

Table 2. The adjusted mean and standard deviation of pig performance due to the use or not of azaperone in postpartum sows.

\begin{tabular}{lccc}
\hline Treatment & W7 & W21 & W59 \\
\hline Azaperone & $2,16 \pm 0,54$ & $5,19 \pm 1,23$ & $20,49 \pm 3,75$ \\
Control & $2,16 \pm 0,53$ & $5,23 \pm 1,21$ & $20,33 \pm 3,56$ \\
\hline CV\% & 24,76 & 23,41 & 17,93 \\
\hline BW & NS & NS & NS \\
\hline
\end{tabular}

BW (birth weight in kg); P7 (weight at 7 days of age); W21 (weaning weight at 21 days of age);

W59 (weight of the nursery with 59 days of age); CV (\% coefficient of variation). NS (not significant).

Concerning mortality rates, transfers, crushed and killed weighing less than $1 \mathrm{~kg}$ at birth, there was no significant difference between treatments (Table 3 ), contrary to the results observed by Jourquin et al. (2010), Miquet and Viana (2010), Jourquin and Goossens (2012) and Pinheiro et al. (2012), who found differences in the mortality rate with benefits for groups from sows treated with azaperone (320 mg intramuscular, single dose) postpartum.
The percentage of piglets treated at the farrowing room as a result of arthritis, weakness and inanition was not significantly different between treatments. In the analysis of medication causes, weak piglets or with inanition and piglets with arthritis, no significant differences were found between the groups (Table 3). The results are similar to those obtained by Pinheiro et al. (2012), who also observed no difference in the incidence of arthritis in the maternity phase and the percentage of animals treated between these two groups. 
Table 3. Mean value and percentages of health and performance parameters observed in piglets during the farrowing phase from submitted sows (Treated Group) or not to azaperone (Control Group).

\begin{tabular}{lcc}
\hline \multirow{2}{*}{ Parameters / Maternity } & \multicolumn{2}{c}{ Groups } \\
\cline { 2 - 3 } & Treated (Azaperone) & Control (Saline) \\
$\mathrm{n}=790(\%)$ & $98(12,64)$ \\
\hline Total mortality & $102(12,89)$ & $228(29,42)$ \\
+Transferred & $260(32,86)$ & $54(6,97)$ \\
Crushed & $48(6,07)$ & $45(31,69)$ \\
Died (weight $<1 \mathrm{~kg})$ & $52(32,70)$ & $115(14,83)$ \\
Medicated & $109(13,78)$ & $41(5,30)$ \\
Weak and inanition & $38(4,86)$ & $24(3,10)$ \\
Arthritis & $18(2,27)$ & $20(2,58) \mathrm{b}$ \\
Diarrhea & $6(0,75) \mathrm{a}$ & \\
\hline
\end{tabular}

Different letters in the same line do not indicate significant differences at $5 \%$ for the chi-square test.

Only the presence of diarrhea was observed difference $(\mathrm{P} \leq 0.01 \%)$, being it lower for piglets from sows treated with azaperone $(0.75 \%$ versus $2.58 \%$ ) (Table 3 ). The percentage of piglets with diarrhea, born of sows treated with azaperone, was 3.44 times lower compared to the control group.

In Brazil, Pinheiro et al. (2012) found a significant reduction $(\mathrm{P} \leq 0.01)$ of $46.69 \%$ in the incidence of diarrhea in piglets from sows treated with azaperone. These results may indicate that the piglets from the treated group, the colostrum intake occurred more evenly, resulting in the reduction of neonatal diarrhea episodes.

Biermann et al. (2010) found a positive effect on the coefficient of variation for the concentration of IgG in the sera of piglets from sows treated with azaperone. A greater transfer of passive immunity to the piglet improves its immunity and therefore reduces the incidence of diarrhea in the maternity phase. Plasma concentrations of $\mathrm{IgG}$ in piglets with 2 days of age and weaning age are positively correlated. Therefore, the higher the passive immunity titer after birth, also the higher serum IgG titer at weaning will be. Thus, the lower the consumption of colostrum ( $\operatorname{IgG})$, the greater will be the susceptibility to infection of the piglets, after birth and weaning (QUESNEL, 2011).
Boulot et al. (2012) and Jourquin and Goossens (2012), respectively, found positive results (P $<0.05$ ) with the use of azaperone about weight gain, uniformity and decreased mortality, and reducing the incidence of diarrhea in the farrowing phase.

Birth weight also influences the intake of colostrum (COSTA, 2007; DALLANORA et al., 2010), in accordance with Devillers et al. (2007) it is related to the vitality and the piglet's ability to stimulate the mammary gland and extract the colostrum, and the heterogeneity of birth weight a possible determinant of variation of this intake.

The weight of piglets at the end of nursery phase was not different between treatments $(\mathrm{P}>0.05)$, indicating no subsequent consequences of using azaperone in this parameter, so keeping consistency with rates from the performance of piglets in the farrowing.

\section{Conclusion}

The use of azaperone immediately after delivery of sows provided a significant reduction in the number of neonatal diarrhea episodes in piglets in maternity period. However, performance results in farrowing and nursery were not affected by treatment. 


\section{References}

BIERMANN, J.; JOURQUIN, J.; VAN GELDEREN, R.; GOOSSENS, L. Facilitating nursing behavior of sows at farrowing has a positive effect on colostrum distribution. In: INTERNATIONAL PIG VETERINARY SOCIETY, 21., 2010, Vancouver. Proceedings... Vancouver: IPVS, 2010. Available at: <http://www.ipvs2010.com/PDFs/ IPVS-Oral\&PosterProceedings(Aug10-10).pdf $>$. Accessed at: 9 set. 2011.

BOULOT, S.; HÉMONIC, A.; JOURQUIN, J. Impact of an azaperone treatment of sows at parturition on sow condition and pre-weaning diarrhea. In: INTERNATIONAL PIG VETERINARY SOCIETY, 22., 2012, Jeju. Proceedings... Jeju: IPVS, 2012. p. 342.

COSTA, W. M. T. Imunidade de rebanho e controle de doenças. In: CONGRESSO DA ASSOCIAÇÃO BRASILEIRA DE VETERINÁRIOS ESPECIALISTAS EM SUÍNOS, 13., 2007, Florianópolis. Anais... Florianópolis: ABRAVES, 2007. p. 1-14

DALLANORA, D.; MACHADO, G. S.; BIONDO, N. Impacto da qualidade dos leitões desmamados sobre o desempenho posterior nas creches e terminações. Acta Scientiae Veterinaria, Porto Alegre, v. 38, n. 1, p. 171180, 2010.

DEVILLERS, N.; FARMER, C.; LE DIVIDICH, J.; PRUNIER, A. Variability of colostrum yield and colostrum intake in pigs. Animal, Sherbrooke, v. 1, n. 7, p. 1033-1041, 2007.

JOURQUIN, J.; GOOSSENS, L. Azaperone, a colostrum management tool. In: INTERNATIONAL PIG VETERINARY SOCIETY, 22., 2012, Jeju. Proceedings... Jeju: IPVS, 2012. p. 823.

JOURQUIN, J.; VANTHILLO, I.; ZOTTI, E.; GOOSSENS, L. Improving sow behavior at farrowing. In: INTERNATIONAL PIG VETERINARY SOCIETY, 22., 2010, Vancouver. Proceedings... Vancouver: IPVS, 2010. p. 887.

MARTINEAU, G. P.; MORVAN, H. Le syndrome faiblesse. In: MARTINEAU, G. P.; MORVAN, H. Maladies délevage des porcs. 2. ed. Toulouse: Editions France Agricole, 2010a. p. 324-327.
. Le systeme locomoteur. In: MARTINEAU, G. P.; MORVAN, H. Maladies délevage des Porcs. 2. ed. Toulouse: Editions France Agricole, 2010b. p. 292-295.

MIQUET, J. M.; VIANA, G. Facilitation of nursing behavior in primiparous sows during colostrums phase improves piglet condition. In: INTERNATIONAL PIG VETERINARY SOCIETY, 21., 2010, Vancouver. Proceedings... Vancouver: IPVS, 2010. p. 160.

MUIR, W. W.; HUBBELL, J. A. E. Manual de anestesia veterinária. 3. ed. Porto Alegre: Artmed, 2001. 432 p.

NATIONAL RESEARCH COUNCIL - NRC. Nutrient requirements of swine. $10^{\text {th }}$ Revised Edition. Washington, D.C.: The National Academies Press, 1998. 190 p.

PINHEIRO, R. W.; MACHADO, S. M.; CARRARO, B.; OLIVEIRA, A. P.; ZOTTI, E. Effect of azaperone administration after farrowing on weight gain and incidence of diarrhea in suckling piglets. In: INTERNATIONAL PIG VETERINARY SOCIETY, 22., 2012, Jeju. Proceedings... Jeju: IPVS, 2012. p. 342.

QUESNEL, H. Colostrum: roles in piglet performance and production by the sow. In: SUINSUI, 4., 2011, Porto Alegre. Anais... Porto Alegre: SUINSUI, 2011. p. 12.

RUEDIGER, K.; SCHULZE, M. Post-farrowing stress management in sows by administration of azaperone: effects on piglets performance. Journal of Animal Science, Champaign, v. 90, n. 7, p. 2331-2336, 2012.

SOBESTIANSKY, J.; BARCELLOS, D. Monitoramentos clínicos. In: SOBESTIANSKY, J.; BARCELLOS, D. Doenças dos suinos. Goiânia: Cânone Editorial, 2012. p. 889-892.

STEIN, M. R.; MURATA, L. S. Colostro: fonte de imunidade suína. Revista Pork World, Campinas, n. 2, p. 48-50, 2002.

STRESNIL. Bula. Beerse: Janssen Pharmaceutica NV, 2009. $2 \mathrm{p}$.

TSENG, S.; JOURQUIN, J.; GOOSSENS, L. Facilitation of nursing behavior in sows during colostrum phase improves piglet condition. In: INTERNATIONAL PIG VETERINARY SOCIETY, 21., 2010, Vancouver. Proceedings... Vancouver: IPVS, 2010. p. 882. 
